\title{
LEGAL REGULATION OF INTELLECTUAL PROPERTY IN THE EUROPEAN UNION
}

\section{Ennan R. E.}

\section{INTRODUCTION}

There can little doubt the importance of intellectual property in the modern world. A successful patented invention can make a fortune for the inventor, or a business empire for the commercial operation created to exploit it. The vast western entertainment industry is dependent for its importance on the protection given to books, performances, records and films by the law of copyright, right in performance, and recording right. Western industry is increasingly aware of the significance to its success of its trade secrets, industrial designs, and confidential internal information.

Finally, and by no means of least importance, in an image-conscious and advertising-led consumer society the importance of trade marks as the primary means by which brands names and image may be protected gallops on apace, a development now emphasized by the now general practice of putting a value on the brand names of a business and including the values in the business balance sheet. Indeed often the value of the brands constitute the major assets of the business.

Given the importance of the intellectual property rights framework to the national economies of the Member States of the European Community created by the Treaty of Rome in 1957, the common market has shown itself to be but poorly designed to handle the consequences of such rights within the community-wide commercial arrangements which it sought to establish. In particular, it has found that the existence of such rights as essentially national rights created by national legislation has an entirely natural tendency to fragment and divide markets on a purely national basis, to the detriment of the principles which caused the creation of the community in the first place and which are intended to inform and direct its everyday operation.

National rights are an inherent obstacle to the creation of a true common market with free movement of goods and services. It is perhaps understandable that in the 1950s the drafters of the Treaty should have failed to appreciate the full extent of the problems which intellectual property potentially posed to the ideals to which they were endeavoring to 
bring practical expression. The ever onward march of the commercial significance of intellectual property rights both nationally and internationally was still in quite early stages. By a process of change which has proceeded at an ever increasing rate of velocity, the commercial world of the 1990s is barely recognizable if placed in direct comparison with the 1950s. It is small wonder that the fathers of European commercial integration should fail to foresee changes which, even with the advantages of retrospect, are incompletely known and understood.

Since intellectual property rights were protected under the Treaty despite their national basis and frequently national exploitation, problems were bound to arise as national rights intruded on community wide trade, particularly in the field of parallel imports, where goods released in one part of the Community might be prevented from importation into another Member State on the grounds that importation would conflict with an intellectual property right existing in that state.

If the drafters of the Treaty failed to appreciate that there was a large problem to which no coherent and consistent reply could be deduced from the Treaty itself, the Commission established under the Treaty terms showed itself much more alert to the unresolved tensions arising from the Treaty provisions, and before the expiration of that founding decade was urging the original six Member States to consider the implications of the national systems for trade marks, designs and patents for the evolution of a true common market. However, such deliberations are inevitably lengthy, and the process of implementation of any recommendations arising from the discussions even longer. The first necessity was to recognize that a real issue exists. This the Court of Justice did quite openly and frankly, stating: "The national rules relating to the protection of industrial property have not yet been unified within the Community. In the absence of such unification, the national character of the protection of industrial property and the variations between the different legislative systems on this subject are capable of creating obstacles both to the free movement of goods and to competition within the Common Market ${ }^{11,}$.

The basic doctrine thus emerges in simple and clear form, but has to be considered in relation to each type of intellectual property separately, if its implications are to be properly perceived. In relation to each type

${ }^{1}$ Parke, Davis v Centrefarm, Case 24/67 [1968] ECR 55. See also Deurkoop v Nancy Dean, Case 114/81 [1982] ECR 2853;

Thetford v Fiamma, Case 35/87 [1988] 3 CMLR 549. 
of intellectual property right - trade marks, patents, design rights, copyright and analogous rights - it has to be asked what are the specific rights associated with this particular right and what are the consequences of the distinction for the exploitation of this particular form of intellectual property right across the Community.

\section{Development of the legal protection of products of intellectual activities}

Copyright. The applicability of the principle of exhaustion of rights to copyright and analogous rights was decided by the Deutsche Gramophone Case itself. However, that case had made its decision on the basis of an assumption - the assumption that copyright and associated rights were industrial and commercial rights within art. 36. If subsequently the issues were actually argued before the Court, and after taking argument it concluded that its assumption had been unwarranted, it could easily follow that the distinction between the essential subject matter of the right and the circumstances of its exercise could be inapplicable to copyright ${ }^{2}$. Subsequently that issue was argued before it in the case of Musik-Vertrieb Membram v GEMA ${ }^{3}$ in part on the basis that since copyright included 'moral' rights it was neither purely industrial or commercial. The Court disagreed and applied to the facts before it the doctrine of exhaustion of rights.

However, while it was thus established that the principle of exhaustion of rights applied to copyright and its neighboring rights no attempt was made to define the specific subject matter(s) of such rights. In fact in wrestling with this problem in subsequent case law the ECJ has found that the position is complex given the very varying ways in which such rights may be exploited. In Coditel $v$ Cine $\mathrm{Hog}^{4}$ the Court held that in the case of a film 'the right that of the copyright owner and his assigns to require fees for any showing of the film is part of the essential function of copyright in this type of literary and artistic work' thus enabling the copyright owner to grant effective licenses for different Member States covering the showing of the film in each state.

On the other hand the specific subject matter of the copyright in a video cassette may differ from that in a film since its usual means of exploitation differs. The exploitation of a video cassette may be by sale,

\footnotetext{
${ }^{2}$ It might still be applicable if the distinction was rebased on art. 222 and not art. 36.

${ }^{3}$ Warner Bros v Christiansen, Case 158/85 [1987] ECR 2605.

${ }^{4}$ Basset v SAC EM, Case 402/85 [1987] ECR 1747.
} 
rental or showing. Whether the commercial rental rights are exhausted by the sale of the cassette depended on whether the law of the country in which the rental took place did, or did not, recognize a rental right separate from the sale, because in the absence of a unified European Community structure in the area national laws inevitably prevailed $^{5}$. By the same token one of the ways on which a record is frequently exploited is by playing in public. Thus, if a discotheque makes use of records in the course of its business and a supplementary fee is payable under national law for this particular mode of public playing, the additional fee is a normal incident of the exploitation of the record even though not levied elsewhere within the community ${ }^{6}$.

Therefore Community law has been consciously developed to try to ensure that copyright owners retain the normal means of exploitation of the various forms of material in which copyright and its neighboring rights may subsist. A necessary corollary of the policy in the application of the concept of exhaustion of rights is that the alleged exhausting act (usually the initial sale by the copyright owner) be a voluntary act. Involuntary activity cannot lead to exhaustion as otherwise the copyright owner's opportunities to exploit his rights would be exhausted without his having any genuine opportunity to exploit them ${ }^{7}$.

Patents. The concept of rights applied in relation to copyright and neighbouring rights was quickly held applicable to the field of patents. In Centrafarm B. V. v Sterling Drug Inc ${ }^{8}$ the drug 'Negram' was being imported into Holland from the UK, where it was sold at a considerably cheaper price. The owners of the mark under which the same drug was to be sold in Holland brought action to try to prevent the parallel import which threatened their profits, relying on an alleged infringement of their patent and trade mark rights. The ECJ applied the concept of exhaustion, holding that the patent rights were exhausted on the sale in the UK, and that the exercise of the rights to prevent parallel importation constituted an unreasonable interference to the free movement of goods. This was compatible with the proper protection of the specific subject matter of a patent which the court found to be 'the guarantee that the patentee...has the exclusive right to use an invention with a view to manufacturing industrial products and putting them into circulation for the first time,

\footnotetext{
${ }^{5}$ EMI Electrola v Patricia, Case 341/87 [1989] 2 CMLR 413.

${ }^{6}$ Bassett v SACEM, Case 402/85 [1987] ECR 1747.

${ }^{7}$ Pharman v Hoechst. Case 19/84 [1985] ECR 2281.

${ }^{8}$ Case 15/74 [1974] ECR 1147.
} 
either directly or by the grant of licenses to third parties as well as the right to oppose infringements.

In this particular case it could be assumed that the patent owner could ensure adequate recompense for himself by the price he attached to the use of the patent in the UK, so that substantially he had exercised his right to exploit the patent in authorizing sale to that particular area of the community. However, it has since been decided that the same principles are applicable if no patent protection is available in the Member State where the patented goods are first marketed, and where, therefore, the invention has no patent protecting it around which the investor can negotiate recompense from protection of a monopoly position ${ }^{9}$. While marketing in these circumstances means that the patent owner is deprived of protection from the eat of parallel imports throughout the Community without having any Duopoly protection in the state in which the sale was made, it can be said at this is the result of the patent owner's choice in marketing in that country in the first place.

More significant problems in patent law have arisen from the licenses of right available in some Member States under which licenses to manufacture a patented product can, in some circumstances, be obtained as of right and without the consent of the owner. In principle the ECJ takes the view that such licenses are obtained without the consent of the owner, and that, therefore, goods manufactured pursuant to such licenses are not put on the market with the consent of the patent owner ${ }^{10}$. However, to this general principle the Court has evolved an exception in the case of patent endorsed licenses of right. These arc licenses of a type which were available under UK legislation under the transitional provision of the Patent Act 1977 where patents given under previous legislation ${ }^{11}$ were given an additional four years protection when the latter legislation came into force. During the extra four years anyone who wanted a license to manufacture goods could have one. When such a license of right was used not to manufacture but to import the patented goods into the UK from elsewhere within the Community the patent owner took action. The ECJ concluded that the distinction between importation and manufacture in the compulsory license would only be justifiable if it were necessary for the proprietor to obtain a fair return from his patent, which in the circumstances it was not ${ }^{12}$.

\footnotetext{
${ }^{9}$ Merck and Co Inc v Stephar B.V., Case 187/84 [1981] ECR 2063.

${ }^{10}$ Pharman $v$ Hoechst, Case 19/84 [1985] 3 CMLR 463.

${ }^{11}$ Patents Act 1949.

${ }^{12}$ Allen and Hanbury v Generics, Case 434/85 [1988] 1 CMLR 701.
} 
Trade Marks. Trade marks have been at the forefront of the evolution of the jurisprudence of the ECJ, since goods which are the subject of underlying patent and copyright type rights are usually marketed under specific marks so that issues of infringement arise as to both the underlying rights and the marks themselves. In addition, trade marks also confer protection on goods unprotected by forms of intellectual property. Thus, the doctrine of exhaustion with its distinction between the subject matter of the trade mark of the right and its exercise came to be early applied within this area of law. The specific subject matter of the trade mark rights is "the guarantee that the owner of the mark has the exclusive right that trade mark for the purpose of putting products protected by the trade mark into circulation for the first time and is therefore intended to protect him against competitors wishing to take advantage of the status and reputation of the trade mark by selling products illegally bearing that mark" ${ }^{\prime 13}$.

While trade marks thus fit simply into the overall structure of the Court's jurisprudence in one respect it has given rise to an especial difficulty. This is the concept of common origin, a concept evolved because the Court has seen the function of a trade mark as that of denoting the origin of goods ${ }^{14}$. Under this doctrine of the Court's jurisprudence where similar or identical trade marks having a common origin are separately owned in different Member States, the owner of one of the marks cannot rely on it to prevent the importation of goods lawfully marketed under the other, since this is seen as being incompatible with the free movement of goods within the Community ${ }^{15}$. The practical implications of the doctrine are well illustrated by the case in which it was first laid down and applied. In Hag I Hag Bremen was a German company which first produced a process for decaffeinating coffee. In 1907 they registered 'Hag' as a trade mark in Germany, and the following year they registered the same mark in Belgium and Luxembourg. In 1935 the two later marks were transferred to a wholly owned subsidiary 'Cafe Hag SA'. In 1944 the assets of Cafe Hag SA including the marks' were expropriated, and ultimately passed into the hands of the plaintiffs in

${ }^{13}$ Centrafarm B.V. v Sterling Drug Inc., Case 15/74 [1974] ECR 1147; Centrafarm B.V. v Winithorp, Case 16/74 [1974] ECR 1183.

14 Franck Schechter 'The Rational Basis of Trade Mark Protection' (1927) 40 Harv. L.R. 813.

${ }^{15}$ Van Zuylen Freres v Hag, Case 192/73 [1974] ECR 713; Terrapin (Overseas) Ltd v Terranova Industrie CA Kapferer and Co., Case 199/75 [1976] ECR 1039. 
1972. Hag Bremen started to export decaffeinated coffee to Luxembourg under the mark 'Cafe Hag' prompting the plaintiffs, Van Zuylen Frercs, to bring infringement proceedings. The Court, however, evolved and applied the doctrine of common origin to reject the claim, concluding that where trade marks sharing a common origin (as here) fall into the hands of different owners in different Member States neither can rely on his mark to prevent importation of goods into his national market.

The doctrine was the subject of considerable criticism since it undermined the principle of consent on which the doctrine of exhaustion was itself built, and had the effect of largely destroying the usefulness of trade marks to protect goodwill in such circumstances. ${ }^{16}$ However, the Court was subsequently given the opportunity of reconsidering this approach to national trade marks, for in 1979 Van Zuylen Freres was taken over by Jacobs Suchard, who as 'Hag Belgium' then proceeded to export decaffeinated coffee under the Hag mark into Germany. This prompted Hag Bremen to try to rely on its trade mark to meet the challenge to its German national market. These infringement proceedings constitute $\mathrm{Hag} \mathrm{II}{ }^{17}$ and they gave the Court of Justice the opportunity to overrule its previous decision. Concluding that its own previous decision in Hag I was wrong, it stated that arts 30 to 36 of the Treaty did not preclude national legislation from preventing the sale within its territory of goods with a confusingly similar mark. While not expressly overruling the doctrine of common origin, it now seems clear that the major issue which the courts will address is not whether or not marks have common origin, but rather whether there is a national goodwill to be protected so that, in the words of the court, 'each of the marks has independently fulfilled within its own territorial limits its functions of guaranteeing that the marked products come from a single source.'

\section{Harmonization and unification of industrial property law}

While the ECJ has achieved a generally commendable degree of success in interpreting the Treaty so as to balance its twin objects of protecting national intellectual property rights and ensuring a freely running regional transnational market, there are clear limitations on how 1981)

${ }^{16}$ D. Gury and G.I.F. Leigh The EEC and Intellectual Property, (Sweet and Maxwell,

${ }^{17}$ CNL-Sugal v HAG, Case 10/99 [1990] ECRI-3711. This is now confirmed by the decision in IHT Internationale Heinztechnik GMBH $v$ Ideal-Standard GMBH, Case 9/93 [1994] 3 CMLR 857. 
much success can be achieved by this route. If Europe is to achieve a genuine integration, European wide intellectual property rights are the logical conclusion of this process. This cannot be achieved by judicial interpretation of the Treaty, and requires direct European legislative activity. This has been long realized. In 1959 the Commission recommended the Ministers of the original six Member States to set up working parties to consider the issues and problems separately for copyright, patents, and design rights. The legislative development arising from this initiative and those arising from other initiatives in the field of trade marks will be the subject of the rest of this overview of this very large topic.

However, one preliminary point needs to be made. Intellectual property is a subject in which policy factors arc usually in high focus, and often in considerable conflict. It is, therefore, often not easy to get the political agreement necessary for change in the very fragmented and politicized legislative machinery under which the community functions. As if that were not enough further tensions arise because of differing views relating to intellectual property protection arising among the Directorate General with responsibilities in this particular area. Most of the Commission's legislative proposals on this subject emanate from DGXV (Internal Market and Financial) which gives greatest weight to the protection of intellectual property rights, whereas DGIII (Industry), DGIV (Competition), and DGXIII (Telecommunications), which also have influence over the legislation, are much more concerned with the impact of the legislation on competition and industrial policy. However, while noting these tensions the eminent specialist Thomas J. Vinje now detects a somewhat healthier trend within the Commission. Writing in the European Intellectual Property Review he comments: "Recently, however, it is fair to say that DGIV has taken a more realistic view to competition cases involving intellectual property. In particular, DGIV has been more willing to accept provisions on intellectual property licensing agreements that might theoretically restrict competition, but that pose little real risk of anti-competitive dangers. DGIV has also liberated the patent licensing, know-how licensing, specialization, and research and developments block exemptions, and have proposed certain further liberalizations of the patent and know-how block inventions". ${ }^{18}$

${ }^{18}$ T. Vinje Harmionising intellectual property laws in the European Union: past, present and future', [1995] EIPR 361. 
The European patent system. The European legislative dimension to patent law has taken two separate principle routes, one within and the other outside the Community as such. It was the system which lies outside the Community which came first, driven not so much by European idealism as the practical needs of industry to reduce the costs of obtaining patent protection within the Continent. Its origins rest not on a European Community basis but on the European Patent Convention ${ }^{19}$, and is thus not restricted to Community members.

Prior to the introduction of the European Patent Convention and its system, patent protection was fundamentally national in character, so that if protection for an invention was required in more than one country separate applications had to be made in each country in which protection was required. Since different jurisdictions have different requirements for patentability (and also differing procedural requirements) the result was slow, complicated and expensive. Increasing internationalization of commercial activity simply gave these fundamental weaknesses wider and more substantial impact. A truly international structure for protection had been the aim of the Paris Convention for Protection of Industrial Property, ${ }^{20}$ it this does not meet the problems arising from the underlying national basis of patent protection since its effect is solely to protect the priority of patent applications made within a participating country within twelve months of the first application in another Convention country. The system is one for the protection of priorities, not for avoiding the needs for separate national applications. Similarly the more recent Patent Co-operation Treaty of $1970^{21}$, while making provision for the filing of an International Application, docs not address the fundamental problem because the so called International Application simply leads to separate individual national consideration of the application in every jurisdiction in which registration is sought.

The European Patent Convention. By contrast, under the European Patent Convention a single application can be made to the European Patent Office (hereafter EPO) in Munich to lead to the grant of a bundle of national patents valid in each country for which a patent is granted. In order for this to be feasible it is necessary that the patentability

\footnotetext{
${ }^{19}$ Convention on the Grant of European Patents, concluded at Munich 5 October 1973.

${ }^{20}$ Dating originally from 1883 this has been revised on several occasions, the most recent being the Stockholm revision of 1967.

${ }^{21}$ This came into effect from June 1978 with an administration provided by the World Intellectual Property Organization in Geneva.
} 
requirements, which differ under national law, should be harmonized by the Convention for the purposes of its own operation and ambit, and this it docs by incorporating many of the harmonizing features of the earlier Strasbourg Convention of the 27th November 1963 on the harmonization of various aspects of patent $\mathrm{law}^{22}$. While there is thus a limited harmonization result arising from the Convention, it nevertheless gives rise to a complex splitting of responsibility for the operation of the intellectual property regime to which it gives rise between, on the one hand, the EPO and the Convention provisions, and on the other, national laws and national courts. Applications may be made initially to either the EPO itself, or to national patent offices who then forward the application to the EPO. The EPO then processes the application and examines the patentability of the invention. If the result is positive a grant of patent is made which, subject to some minor formalities, has the effect of conferring patent rights in each country covered by the application. With the exception of opposition proceedings mentioned below, the function of the EPO ends with the patent grant, which confers the same status on each national grant as it would have enjoyed under the law of that country. Consequently, matters of infringement or revocation fall to be dealt with under the national law of each country in respect of which the patent is granted. As a further consequence, a finding by one national court affects the patent in that country only, the effectiveness of the patent in other countries being unaffected. Exceptionally, however, opposition proceedings attacking the whole patent may be brought in the EPO within nine months of the publication of the patent by any opponent able to establish a sufficient ground, and successful opposition proceedings lead to the loss of the whole bundle of national patents.

Clearly, the fact that the treatment of the patents after the grant is dependent on the national laws of each country concerned is a definite weakness of the system. This is clearly understood, and the Convention docs envisage increasing harmonization of these areas of national law, although this will almost certainly prove extremely difficult to achieve. Nevertheless, the Convention has proved to be extremely popular. This is hardly surprising. Although the treatment of patents after registration remains to be harmonized, the harmonization of patentability itself is an

${ }^{22}$ Like the European Patent Convention itself the Strasbourg Convention was not a Community initiative or in any way directly related to the Community. It was promoted by the Council of Europe. 
immeasurable simplification of the complex pattern of differing national requirements in this respect, and, at a practical level, a great contributor to efficiency and cost savings.

The Community Patent Convention. However, whatever the practical solutions which emerge from the European Patent Convention, it still remains true that its provisions do not provide a framework under which a Community wide patent can be obtained and maintained independently of national laws and enforcement. This is hardly surprising since, as has been noted, the European Patent Convention was not the result of a European Community initiative. This does not mean, however that the Community was indifferent to this area of intellectual property. A; result of the initiative of the Commission in 1959 a report on patents $\mathrm{V}$ prepared which recommended, inter alia, the creation of a true Community patent. ${ }^{23}$ The result was the Community Patent Convention signed on 15th December 1975. There have proved to be difficulties in obtaining ratification of all Member States. Denmark and Ireland in particular have experienced political and constitutional difficulties in proceeding to ratify, despite agreeing the text of the draft. A conference held at Lisbon on 3rd and 4th May 1992 failed to find a solution to the difficulties. It is becoming increasingly unlikely that the draft Convention will ever receive the force of law.

In form the Community Patent Convention seeks to build on the structure created by the European Patent Convention, giving to the EPO the task of registering and maintaining community patents in special departments established for the purpose. The great difference between the two systems (apart from possible differences in the countries which choose to participate in the two regimes) is that the Community patent is a single patent covering the whole of the Community, and not a bundle of national patents having separate existence under the separate laws of the individual participant states. Thus, the terms of the Convention seek to cover not merely registrability, but also matters of infringement and revocation. Under the regime established under the Convention, certain courts will be specified in each country as Community patent courts of first instance, having jurisdiction over both validity and infringement. Appeals will be dealt with by certain national courts of appeal in each country, which will be second instance, Community patent courts. Over

${ }^{23}$ Convention for the European Patent for the Common Market (the Community Convention) and the 1989 Luxembourg Agreement relating thereto OJ 1989 L 401/1. 
the whole structure there will exist a newly established Common Appeal Court to which issues of validity or infringement may be referred. It will also be possible to challenge at any time the validity of a Community patent before the EPO under its responsibilities for acting as the Community Patent Office.

Protection of Trade Marks. As with patents it is important also with trade marks to place European developments against the background of international law, if their significance is to be properly appreciated. The oldest relevant international intervention into the field of trade marks and their protection is the Paris Convention for the Protection of Industrial Property, but this is far more concerned with securing the provision of minimum protection by the national laws of its participating states than providing a transnational system for trade mark protection. By contrast The Madrid Agreement for the International Registration of Marks 1891 is much more comparable to the regime of the European Patent Convention. Under its provisions once a registration has been obtained under the national law of one of the participating states the owner of the domestic registered mark thus obtained may apply to the International Bureau of the World Intellectual Property Organization for an international registration. The Bureau then passes the application to the national trade mark registries of all participating countries in which registration is requested, who then may grant national trade marks. Effectively, therefore, the international application represents a batch of individual applications which then fall to be considered under the national laws, and which, if successful, leads to a bundle of trade marks depending on the relevant national laws for their validity and enforcement. Clearly such an approach is inadequate at a Community level, since it produces neither harmonization between the requirements of different national systems of law, nor a truly transnational system for registering and/or maintaining and enforcing trade mark rights within the Community.

European Community reform of trade marks addresses both problems. As part of the single market initiative the Council of the European adopted the First Trade Marks Directive of 21st December $1988^{24}$ on the approximation of national trade mark laws and the Council Regulation (EC) of 20th December $1993^{25}$ on the Community trade mark.

${ }^{24}$ First Council Directive 89/104/EEC to approximate the laws of the Member States relating to trade marks: OJ 1989 L40/1.

${ }^{25}$ Council Regulation 40/94 on the Community Trade Mark: OJ 1994 L 11/1. 
As their names imply the purpose of the Directive is to introduce a large degree of harmonization of national trade mark law, and the purpose of the Regulation is to introduce a Community wide trade mark based on a European central register.

While the purpose of the Directive is to achieve a greater degree of harmonization than that previously exhibited by the very different trade mark systems of the Member States of the Community, it does not seek to achieve total harmonization. Its aim was to reduce the substantive differences between national systems which operated as barriers to trade at a practical level, thereby hindering the free movement of goods and services and the development of a true single market. It thus concentrates on approximating the national laws of the Member States by specifying what can be registered as a mark, the scope of the right which accrues if registration is achieved, the ownership of the mark, and how a registered mark may be licensed and revoked. By contrast the procedural aspects of application and registering, infringement and revocation proceedings and procedures are left to national laws. Further, even in respect of matters with which the Directive does deal some of its provisions arc mandatory whereas others are optional, with the result that the latter can be ignored by those Member States that wish to do so. The result of implementation of the Directive will thus lead to a greater approximation of national laws, but not to uniformity.

The Directive draws very considerably on Benelux trade mark law which was perceived to be the most developed within the Community. The drafting of the Directive is in wide and general terms, and when interpreted by the ECJ will be subjected to a teleological style of interpretation making use of the available travaux préparatoires. In this particular case these include the Explanatory Memorandum of the Commission which preceded the first draft of the Directive in 1980, and the minutes of the meeting of the Council of Ministers which adopted it. The combination of the wide, indeed often general, terms of the Directive and this approach are likely to have the effect of giving a very wide impact to the Directive.

The Directive seeks to define a trade mark in terms of what it sees as the basic function of a trade mark, which in economic and legal terms, it sees as 'to indicate the origin of goods and services and to distinguish them from those of other undertakings'. Within the restrictions of these concepts trade marks are widely defined. 'A trade mark may consist of any sign capable of being represented graphically, particularly words, 
including personal names, designs, letters, numerals, the shape of goods or of their packaging, provided that such signs are capable of distinguishing the goods or services of one undertaking from those of other undertakings'. The Directive sets out a harmonizing structure for registrability, enforcement, licensing and revocation of marks, the adoption of which will bring national laws much closer together. Within the structure one particular provision is perhaps worth special mention. Art. 7 acknowledges the accumulated jurisprudence of the ECJ on its concept of doctrine of exhaustion of rights and seeks to summarize it, thus perhaps providing à framework from which it will become embodied in national legislation.

While harmonization of the domestic laws of the Member States of the Community is no doubt highly desirable, it does not create the means by which a community wide registration can be affected. All that it achieves is to make more comprehensible and uniform the domestic laws, under which individual applications within those states will be considered, as the proprietor seeks to build up the bundle of national rights which he will require to enjoy protection across the Community. The more radical step however, emerges from the second Community initiative, the Community Trade Mark Regulation. This provides the means by which a Community wide trade mark can be obtained by registration at a European central registry. One of the main functions of the Regulation is, therefore, to provide for the creation of a Community Trade Mark Office (the CTMO, in fact called officially the Office for the Harmonization in the Internal Market (Trade Marks and Designs), which is sited at Alicante in Spain.

The provisions relating to registrability and maintenance on the register of the Regulation are in very similar terms to those of the Directive. A Community trade mark can only be obtained by registration, and not by length of use and reputation. Since registration may be refused on the ground that the mark would conflict with an existing mark whether registered under national law or as a Community mark at the CTMO, it will be necessary to cause searches to be carried out both in Alicante and the national registers of those Member States which are affected before lodging an application. An application must be filed at CTMO or at a national trade mark registry. In the latter case the application must be forwarded to CTMO within two weeks.

Of course registration merely creates a property right which requires a structure of recognition and enforcement. Property rights are matters for the national laws of Member States themselves, and the Regulation is 
obliged to work within this framework which is, or course, dictated by the Treaty itself. The property right has therefore to be tied to the national property rights of a Member State. Art. 16 of the Regulation achieves this by providing that a Community trade mark as an object of property shall be dealt with in its entirety, and for the whole area of the Community, as a national trade mark registered in the Member State in which, according to the Register of Community trade marks the proprietor has his scat and domicile or, if he lacks both, his establishment. This then gives a legal framework for the existence of the property right. Its scope and extent is similar to that which arises for national marks under the Directive. However, the enforcement of the Community Trade Mark Right is left to national law although, as with patents, there will be a first and second tier of designated 'Community Trade Mark Courts' in each country with referral powers and responsibilities to the ECJ under art. 177. In this respect the harmonization of national laws from the Directive should be seen as a necessary and powerful ingredient in the Community Trade Mark framework itself.

Industrial Design Right. The protection of industrial design is an area of vast importance. Industrial design allows the product design of products and parts of products to be protected where there is novelty in a design feature, but where there is no invention protectably by patent. Most industrial products will have elements of design protection, so that the majority of manufactured goods the subject of trade between Member States within the Community will be subject to design rights. As examples television, motor cars, hi-fi contain large numbers of parts all or some of which may be subject to design rights, each of which represents considerable economic value to its owner. To register the right in each Member State in which business is done represents a considerable financial and operative expense.

Almost inevitably increased practical importance leads to increased political significance. Its increasing importance is also indicated by the level of litigation which it prompts. Keverkoop v Nancy Kean Gifts ${ }^{26}$, Renault $\mathrm{v}$ Maxicar ${ }^{27}$, and Volvo $v$ Veng $^{28}$ were all cases on design protection. It was in the specific area of design protection that the ECJ laid down that in the absence of a Community-wide framework for a

\footnotetext{
${ }^{26}$ Case 144/81 [1982] ECR 2853.

${ }^{27}$ Case 53/87 [1988] ECR 6039.

${ }^{28}$ Case 238/87 [1988] ECR 6211.
} 
specific area of intellectual property, the exercise of national property rights would not automatically be found to be an abuse of a dominant position. In the absence of a unified system national right owners are able to rely on those rights unless the particular exercise is abusive.

This, however, merely indicates that the economic considerations and policies on which the Community is based demand that harmonization and unification be used to overcome the economic disruption which flows from having a complex system of national rights having the potential to fragment a single market. The problem is to achieve that harmonization. In no other areas of intellectual property are the differences between national laws more pronounced ${ }^{85}$. it is this which makes harmonization and unification so difficult to achieve. At the same time, however, it is the particularly pronounced range of national approach which makes that harmonization and unification so specially needed.

While the problems in this area are particularly acute, the Community's interest goes back to 1959 when the working party on designs was part of the three pronged approach to the harmonization of intellectual property. The report of the working party pessimistically concluded that differences in national laws were so pronounced that no attempt at harmonization was feasible, but that nevertheless there was room for a community design system to co-exist with the very different national frameworks. No doubt infected by the pessimism of this report the Commission gave priority to the more promising possibilities of other areas of intellectual property, largely ignoring design protection. However, when the Green Paper on copyright was published the Economic and Social Committee noted the lack of progress in the area of designs $^{29}$, and expressed the hope that proposals in that area would not be long delayed. The Commission responded with a Green Paper on industrial design in June $1991^{30}$.

The Green Paper adopted a twin approach to design protection within the Community, a formula very similar to its framework for trade mark protection, which is built also on a draft Regulation and a draft Directive. The draft Regulation is similar in mode to the draft trade mark Regulation, which, may be seen as its basic model, and has the purpose of creating a Community wide design right, based essentially on registration but with a

${ }^{29}$ OJ 1989 C71/9; Bull EC Supp. 1-1989, point 2.1.7.

${ }^{30}$ Green Paper on the Legal Protection of Industrial Design, Working Document of the Services of the Commission, III/F/5131/91-EN. 
provision for a short period of unregistered protection. Under the Regulation designs would have an unregistered design right which would protect them for a limited term of three years from unauthorized copying. If a longer period were desired, the design could be registered and would confer a monopoly to use the mark for an extended period. In addition an initial grace period of protection conferred by the unregistered design right would run for a period (tentatively suggested as one year) from the date of disclosure to the public. Often this will be when articles to the design are first marketed to the public. Such disclosure will not destroy the novelty, and hence the registrability of the design. Thus, test marketing of a product would not destroy its registrability, and registration could be sought if the indications from the test marketing proved to be favorable. Thus, unregistered design rights would not come to an end at the end of the grace period but would continue for a further period of two years. This recognizes diat a system of protection which does not require registration is appropriate to those designs which enjoy relatively short lives such as fashions. By contrast the period of protection flowing from successful registration would be 25 years (an initial term of 5 years plus four possible five year renewals on payment of further fees). The creation of a Community wide system of registered design requires the setting up of a Community Design Registration Office similar to the Community Trade Marks Office at Alicante.

\section{CONCLUSIONS}

To achieve these ends the draft Directive seeks to achieve a harmonization of the very disparate national laws of the Member States in relation particularly to registrability, scope, and duration of the design rights conferred by national systems of registration. It does not therefore address the issue of unregistered design for registration purposes. The failure to address the issue of the existence of unregistered design protection might seem on the surface to cause difficulties for the UK use of this as a means of protecting functional designs introduced by the Copyright Designs and Patents Act $1988^{31}$. However, the Directive neatly disposes of this potential problem by treating the UK system of unregistered protection as a species of copyright, and therefore something which can be simply ignored. More significantly however, the use of copyright to provide protection to

\footnotetext{
${ }^{31}$ Copyright Designs and Patents Act 1988, Part HI, p. 213-264.
} 
designs which are themselves artistic works is protected by the Directive which requires that such protection must be without restriction 'irrespective of the number of products in which such design is intended to be incorporated and/or to which it is intended to be applied, and irrespective of whether the design can be dissociated from the products in winch it is intended to be incorporated or to which it is intended to be applied'. This hits the industrial application rule applied by the laws of the UK and Eire which limits the duration if more than 50 articles are made to the design, and also the Italian requirement of scindibilita which turns on whether the aesthetic features of the design can be separated from the functional features of the product.

Both the Draft Regulation and Draft Directive in the original forms published by the Commission drew a great deal of criticism from industry, practitioners and other groups who considered their interests affected. Given the great differences between the various national laws to be harmonized design protection was always going to be controversial. The weight of the criticisms was considerable. In the light of them the Commission deliberated further and subsequently produced substantially amended drafts, which, however, retain the broad approach outlined here. The new drafts remain extremely controversial and it must remain questionable as to whether an appropriately speedy resolution of these particular problems of European intellectual property law can be effected. It would be unfortunate if it cannot.

\section{SUMMARY}

The article investigates the development of the concept of intellectual property law in the EU. One of the difficult issues in legal science is value and delimitation of the exclusive rights (intellectual property rights) and proprietary rights (classical property rights) as well as the feasibility of using the concept of "intellectual property". World jurisprudence and practice suggest different approaches legislators and the legal profession to address these issues.

The basic doctrine thus emerges in simple and clear form, but has to be considered in relation to each type of intellectual property separately, if its implications are to be properly perceived. In relation to each type of intellectual property right - trade marks, patents, design rights, copyright and analogous rights - it has to be asked what are the specific rights associated with this particular right and what are the consequences of the 
distinction for the exploitation of this particular form of intellectual property right across the Community.

\section{REFERENCES}

1. Bainbridge David I. Intellectual property / David I. Bainbridge. 5th ed., 2002.

2. Cornish W.R. Intellectual Property. - 1996. - 722 p.

3. Eastaway Nigel A. Intellectual property: law and taxation / Nigel A. Eastway, Richard J. Gallafent, Victor A.F. Dauppe. - 6th ed., 2004.

4. Keeling David T. Intellectual property rights in EU law / David T. Keeling. Volume 1, 2003.

5. Marshall, James. Non-contentious intellectual property / James Marshall, 2003.

6. Matthews Duncan Globalising intellectual property rights: the TRIPs Agreement / Duncan Matthews, 2002.

7. Tritton Guy. Intellectual property in Europe / Guy Tritton. $2^{\text {nd }}$ ed., 2002.

8. Audrey Horton. European design law and the spare parts dilemma: The proposed Regulation and Directive // European Intellectual Property Review. - 1994. - N 16(2). - P. 51-57.

9. Alexander Bulling, Angelika Langohrig, Tillmann Hellwig. The Community Design: A New Right of Design Protection for the European Community // Journal of the Patent and Trademark Office Society. February, 2004.

10. Briffa, Margaret. Design law: protecting and exploiting rights // Margaret Briffa and Lee Gage, 2004.

11. Graeme B. Dinwoodie. Federalized Functionalism: the Future of Design Protection in the European Union // AIPLA Quarterly Journal. Spring-Fall 1996.

12. Hugh Griffiths. Overview of developments in Europe on industrial design protection // Fordham Intellectual Property, Media and Entertainment Law Journal. - Summer, 1993.

13. Musker David C. Community design law: principles and practice / David Musker, 2002.

14. Robin Whaite. Pharmaceutical Patent term restoration: the European Commission's Regulation // European Intellectual Property Review. - 1992. - N 14(9). - P. 324-326.

15. Suthersanen Uma. Design law in Europe: an analysis of the protection of artistic, industrial and functional designs under copyright, 
design, unfair competition and utility model laws in Europe, including a review of the B.C. design regulation, the E.G. design directive and international design protection / by Uma Suthersanen, 2000.

Information about the author: Ennan R. E.

PhD in Law, Associated Professor at the Department of Intellectual Property Law, National University "Odessa Law Academy” 2, Academychna str., Odessa, 65009, Ukraine 